\title{
The connection between the depopulation of localities and passenger rail services in the Province of Buenos Aires in Argentina between 1960 and 2009
}

\author{
Juan Manuel Diez-Tetamanti ${ }^{1}$, Melisa Pontrelli-Albisetti ${ }^{2}$ \\ ${ }^{1}$ National Council of Researching and Technology, Argentina.Profesor National University of Patagonia San Juan Bosco, Argentina \\ ${ }^{2}$ National Council of Researching and Technology, Argentina Centre of Geo and SocioEnvironmental Researching; National University \\ of Mar del Plata
}

\section{Email address:}

jmdiezte@gmail.com,jmdiezt@unpata.edu.ar (J. M. Diez-Tetamanti), melisa.albisetti@gmail.com(M. Pontrelli-Albisetti)

\section{To cite this article:}

Juan Manuel Diez-Tetamanti, Melisa Pontrelli-Albisetti. The Connection between the Depopulation of Localities and Passenger Rail Services in the Province of Buenos Aires in Argentina between 1960 and 2009. Social Sciences. Vol. 2, No. 4, 2013, pp. 154-160. doi: $10.11648 /$ j.ss.20130204.12

\begin{abstract}
Between 1960 and 2001 there were two processes that drew the interest of some social researchers in Argentina. On the one hand there was a process of rural depopulation from localities in the province of Buenos Aires (similar to the process of urbanization across Latin America). On the other hand, there was the break up of the railways that led to the cessation of passenger services to hundreds of localities inside the province of Buenos Aires. This study compares the two variables -localities in the interior of the province of Buenos Aires that lost population and railway lines which recorded decrease in the provision of passenger transport services. Census data and rail traffic between 1960 and 2009 are used. This crosses a quantitative methodology with concepts that the geographer Milton Santos has proposed. Maps are generated to look for any correspondence between these variables. Finally the concept of lag is applied to observe possible temporal relationships between variables. The results represent a first approach to a subject that has never been addressed with this methodology and analysis tool, verifying that it is necessary to incorporate more data to facilitate further analysis.
\end{abstract}

Keywords: Population, Depopulation, Localities, Railroads, GIS, Buenos Aires, Argentina

\section{Introduction}

In Argentina, the railroads were built by British, French and Belgian companies, and by the state itself. In the Province of Buenos Aires - the largest and most populous of Argentina -the railway was built mainly using British capital in the late nineteenth century. In 1947, all private railroad companies were expropriated by the government of Juan D. Perón. Furthermore, a national company was set up to manage the Argentina railway network until 1992, when it was leased.

From 1960, Argentina experienced an increased use of cars that combined the relationship between the three elements - techniques, objects and space. All of them were reflected in the vehicle fleet, which increased from 23.1 people/ vehicle in 1960 to 6.5 people / vehicle in $1980^{1}$. Parallel to this process, there was a decrease of passenger services by rail, which is reflected in the analysis developed

Data elaboration based [16]; [17] and [18]. in this paper.

There was a rise in the urban population ranging from $72 \%$ in 1960 to $89.3 \%$ in 2001 [1], also expressed in the depopulation of the Rural Cluster [2; p.3], concerning localities between 200 and 2000 inhabitants.

Scientific literature analyzes the problem of depopulation in localities, related to the cancellation of train services and the decline of absolute population expressed by authors [3]; [4]; [5] and [6]. However, beyond the qualitative analysis of the problem, there are no studies that cross variables: population and passenger rail services. What is the relationship between the process of depopulation within the Province of Buenos Aires and the decline of railway services? Could there be the direct relationship established between the two variables that some authors propose?

This paper is based on data processing performed for the doctoral thesis «Local actions and policies in the Province of Buenos Aires» ${ }^{2}$. This work included: census data, and

Defended on March 30, 2012 at the Department of Geography.National University of the South. Bahía Blanca. Argentina [15] 
periodized passenger rail services between 1960 and 2009.

The data were processed and georeferenced by free software (QuantumGIS; Kosmo GIS 1.7 and 2.0 RC1) and this then generated contributions to the analysis of these variables.

This work represents a breakthrough in cross referencingpopulation data digitization with rail transport data, which at the time of research, contained large gaps or was unable to be accessed using previous methodologies.

Methodology

Area of study:

The area of study is limited to the political boundaries of the Province of Buenos Aires, Argentina. The province of Buenos Aires is the largest and most populated state with $307571 \mathrm{Km}^{2}$ and 15,524,428 inhabitants, which represents $38 \%$ of the country's population.

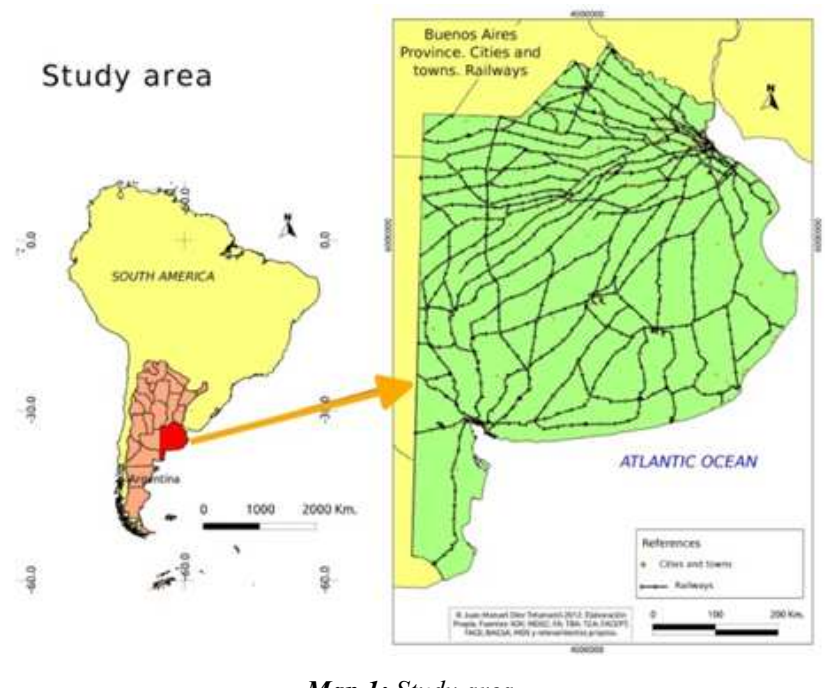

Map 1: Study area

The railway network of the province of Buenos Aires is under the influence of a space derivative [7] from railway construction between 1857 and mid-twentieth century. The network (operating and non-operating) extends 18648.30 kilometers, representing $39.6 \%$ of the 47,059 kilometers across the state.

To carry out the study a total of 563 localities were surveyed by the National Geographic Institute (Argentina) between 1960 and 2001. The population rose from 200.000 to 500.000 inhabitants in the census conducted by the National Institute of Statistics and Censuses over the years 1960,1970,1980, 1991 and 2001. For the construction of railway databases, 305 segments of the branches were taken (distributed along of $18648.30 \mathrm{~km}$ ), which were divided from the variation in the provision of passenger rail services.

\section{Periodization Data and Map Construction}

In the processing, two GIS GNU: Kosmo GIS and Quantum GIS 2.0 RC1 (QGIS 1.7) are implemented. For all the shapes flat coordinate system is worked: WGS 84 datum and projection Gauss Kruger, belt 3 .

On the basis of 563 localities identified by the National Geographic Institute, those who had comparable census data were used. That is, they exist as localities surveyed by the INDEC and their census information can be compared. Thus, of the 505 initial localities only 489 were studied.

For railway passenger services, we used the total network of the province of Buenos Aires. Therefore, the reference used was the operating timetable of Argentinean Railways for the years 1960, 1971, 1980 and 2001-9 [8]; [9]; [10] and[11]. The break in passenger rail services was based on existing and available data ${ }^{3}$. However, the main break in passenger rail services happened in 1992, when the railway service was leased by the Executive Unit of Provincial Railway Program (UEPFP).

\section{Methodological Steps}

a) Census data was collected as well as weekly passenger services. This was done as part of the doctoral thesis, the INDEC and the Provincial Department of Statistics of the Province of Buenos Aires. In line with the formal guidelines for access to the information, older data were photographed as well as digital copies of the databases. After that, work was done by extracting rail data contained in the books of operating timetables for seasons: 1961, 1971 and 1980 in the six national railway lines: General Roca (GR), Domingo Faustino Sarmiento (DFS), General Mitre (GM), General Belgrano (GB), General Urquiza (GU) and General San Martin (GSM). Timetables data were reviewed for the branches that cover the province of Buenos Aires, counting the weekly passenger trains.After 1989 , the next season that was reviewed was 2009 , because of the irregularity of services after 1992. Thus, we used the data provided by companies: Executive Unit of Provincial Railway (UEPFP)-GR lines; DFS and GSM Buenos Aires Trains SA. (TBASA)GM-line; Railway Management and Operation Unit (UGOFE) GR and line Special Argentine Trains (TEA) GU-line.

b) In a second step we proceeded to correct the initial "shapes" (Census and Railways) and then to load data, perform information integration, editing, updating and processing information in georeferenced databases.

Shapes belonging to the Laboratory of Geographic Information Systems, Department of Geography, and National University of Patagonia San Juan Bosco, were used. Finally, census data since 3732 to 489 localities and 305 railways, for each reporting period was loaded and

The origins of the data sources can be used in the literature. However it is worth noting the extra official multiple data used, especially in the case of railways. This is seen mostly from the 1990s. The absence or the mess of data in many agencies as ComisiónNacionalReguladoradelTransporte (CNRT) or OrganoNacionalAdministrador de Bienes del Estado (ONABE) is an item of concern when you consider that it is the State who makes policy interventions with greater impact. 
reviewed.

Thus periodical shapes were constructed with variables that were based on population data for $1947,1960,1970$, 1980, 1991 and 2001. In turn periodical shapes were constructed for weekly services for passenger rail (WPS Railways) for the years 1960, 1971, 1980 and 2009[8]; [9]; [10] and [11]. In some special cases of the database, we had to update and supplement existing information which in many cases was incomplete. Tables were generated from the data, and symbols were established for the purpose of making comparisons. The introduction of diachronic and synchronic shapes is presented as a step in mapping data indicative of territorial dynamics within the province of Buenos Aires, during a period of 49 years (between 1960 and 2009) ${ }^{4}$.

As part of the theoretical line of Milton Santos [12], periodization was addressed with dynamic variables, centralized actions, functional technology implanted in space and the rules that mediate them.We cross referenced these variables with synchronic and diachronic shift modes for later impact analysis.

\subsection{Construction of Shapes and Maps}

\subsubsection{Population}

After loading the total census data for each point (location), and understanding that the Argentine censuses were conducted with variations of periodization (some ten years and another every 11 years), we used the formula «Annual Percentage Changes of the Population» (APCP) where the real variable is the total population (for each location on a specific date-census-) calculated from the following formula. This allows comparisons between maps covering different periods of time [13; p.19].

$$
A C P C=\left(\sqrt[n]{\left(\frac{P 2}{P 1}\right)}-1\right) * 100
$$

Where:

P1 = Population in the initial year of period

Year Population P2 = end of period

$\mathrm{n}=$ total number of years of the period

This will generate the maps' Annual percentage of the population, for periods 1960 - 1971, $1971-1980,1980$ 1991 and 1991 - 2001 (In case of censuses 1980, 1991 and 2001 we estimated total percentage annual change 1980 2001 on the occasion of comparisons with data rail).

After obtaining the filtered maps, APCP negative variations results were obtained for each locality. Thus negative APCP maps for the same periods were obtained.

\subsubsection{Railway}

After loading the data from each of the segments and branches, and the data of the weekly passenger transport

To which is added the time period is not included in this paper with values census 1947 (digitized) and other utilities such as electricity, gas and rural schools toggle [19]. services, we proceeded to build shapes by rank, and compare the years $1960-1971-1980$ and 2009 (the latter is taken based on irregularities in service delivery between 1992 and 2009). Then, the formula above was used, replacing the population data with P1 and P2 Weekly Passenger Services (WPS1 and WPS2). The branches data were compared with APCP (-) (Services), and the decrease summarized as: APCP (-) WPS.

To make the link between the declining provision of weekly passenger services [Localities APCP (-)] and the annual variation in the decreasing population [WPS-APCP $(-)$ ] was performed with 2500 meters buffer on each side of the railroad.

This solved the problem created by the fact that the location of the points (localities) are not usually coincident with the railway line - that is that themarked location centre or centres upon geo-referencing are not precisely coincident with the trace rail.

A buffer was used with the spatial query tool which included each of the period Localities APCP (-) remaining within the WPS APCP buffer (-).

Thus, the results were obtained for the linkage between shapes, which were then tested with a lag $[7 ; \mathrm{p} .134]$ ten years later to analyze the impact of declines in passenger services.

\section{Results and Mapping}

The results are presented in five maps(view maps series) representing different tie periods. Since there was no correlation between census periods and periods of WPS available to analyze, the closest parameter was established.

Map 2: data for the time period (1960 to 1970 census) (1960-1971 WPS) were obtained for 11,329 kilometers of railways with reducing WPS. This represented 103 affected branches. The annual average reduction was $-8.63 \%$ WPS for the total affected branches. In terms of spatial query, there were 56 localities (72.7\%) with APCP (-) branches located beside railroads with APCP WPS (-) from a total of 77 localities APCP (-). The APCP (-) of localities affected stood at $-1.28 \%$.

Map 3: Data for the time period (1970 to 1980 census) (1971-1980 WPS) were obtained for $8897 \mathrm{~km}$ of railways with reducing WPS.This represented 104 affected branches. The annual average reduction of WPS was $-16.13 \%$ for the total affected branches. In terms of spatial query, there were 71 sites $(57.2 \%)$ with APCP (-) branches located beside railroads with APCP WPS (-) from a total of 124 localities APCP (-). The APCP (-) of localities affected stood at $-1.86 \%$.

Map 4: data for the time period (1980 - 1991 - 2001 census) - (1980-2001 WPS) were obtained from $7421 \mathrm{~km}$ of railways with reducing WPS. This represented 77 affected branches. The annual average reduction of WPS was $-98 \%$ for the total of the branches affected. In terms of spatial query, there were 56 localities (34.1\%) with APCP (-) branches located beside railroads with APCP WPS (-) from 
a total of 164 localities APCP (-). The APCP (-) of localities affected stood at $-0.91 \%$.

Map 5 : data for the time period (1970 to 1980 census) were used to create a lag period (1960-1971 WPS) where: in terms of spatial query, there were 80 localities $(64.5 \%)$ with APCP ( -) branches located beside railroads with APCP WPS (-) from a total of 124 localities APCP (-). The APCP (-) of localities affected stood at $-0.91 \%$.

Map 6 : data for the time period $(1980-1991-2001$ census) was used to create a lag period (1960-1971 WPS) where: in terms of spatial query, there were 101 localities (61.5\%) with APCP (-) branches located beside railroads with APCP WPS (-) from a total of 164 localities APCP (-). The APCP (-) of localities affected stood at $-0.91 \%$.

The results show that APCP to time (-), in localities which registered the largest annual decline, is best captured between 1960 and 1980, and more clearly from 1970 to 1980. In parallel, the same phenomenon happens for the provision of WPS. Both variables fall in this period. Then between 1980 and 2001 the average value of APCP (-) increases in localities and APCP WPS (-) decreases almost completely.

The relationship between the two variables has shown a certain parallelism in the 1960s, 1970s and until 1980.In cartographic outputs, the relationship between APCP (-) in localities in APCP WPS (-) is also greater in those decades. In the 1990s, the APCP (-) in localities continues even unrelated to the branches affected by WPS APCP (-). This is also explained in the $90 \mathrm{~s}$, by the fact that the WPS Railways was reduced and the possibility of linking the variable statistical APCP with APCP localities WPS is almost invalid.

\section{Discussion}

In Argentina, the issue of declining rural population and rail service delivery represents a research problem which is usually addressed with a qualitative analysis. Academically, and as "common sense", it has been accepted that there is a direct relationship between the closure of rail services and the problem of depopulation. There has not previously been analysis which quantitatively linked the population variables and weekly services for passenger rail, using Geographic Information Systems.

From the crossing of these variables, including the concept of "gap" in the methodology, a relationship is indicated for the years 1960 and 1980, between the problems of depopulation in districts declining services provided by the railroad. However, from 1980 to 2001, in absolute terms, the number of APCP (-) localities between the period 1960 and 2001 grew from 72 localities to 164 localities, increasing by $127 \%$, while the performance WPS is reduced by $98 \%$.
Connoction betwoen ACPC $(\cdot)$ from localities and ACPC $(\cdot)$ form WPS $1970-2001$

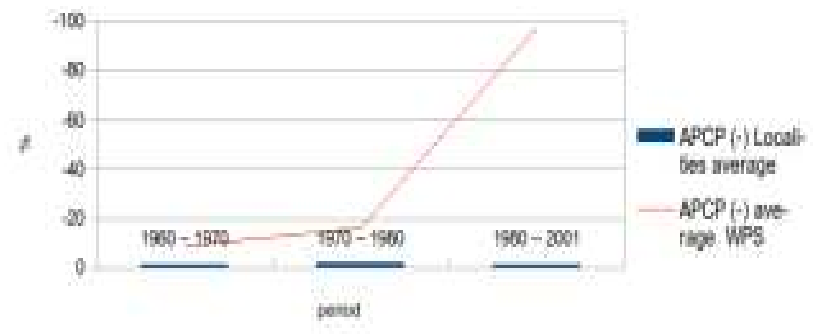

Figure 1. Connection between ACPC (-) from localities and ACPC (-) form WPS 1970 - 2001.

The scrapping of rail in Argentina, both literally and metaphorically, involved an initial functional interdependence between the localities of the interior especially the smaller, more dynamic areas that existed until the mid-twentieth century - and the railroad. Thus, the results showed that the first decades of reducing WPS (1960 and 1970,) beginning with the implementation of the Larkin plan [14] and the FFCC interventions of adjustments and permanent cuts, were marked by an accompaniment in the APCP (-) localities, as shown in the Map 2; Map 3; Figure 1 and Figure 2.

The data suggest that in 1960s and 1970s two processes occur within the province: the depopulation and the dismantling of rail.

These two phenomena are discussed in the academic literature over many years. However, academia should also address the processes of "automotorization", that is, the rapid increase in the number of cars and the general privatization in mobility and transport. [15; p.153].

The resulting data reflected on maps 4,5 and 6 do not provide a direct link between the variables analyzed, however, the application indicates an inertia lag in the impact of the APCP (-) on the APCP WPS (-) localities and leads to the generation of new questions: What other factors influenced the increase APCP (-) localities? Which of these elements are feasible to work with periodization techniques in GIS? Finding the causes and quantifying other processes involved in the APCP (-) in localities to establish a more accurate diagnosis.

It is evident that reducing the WPS FFCC from 1980 stops having a relevant APCP correlation with the (-) localities, and therefore, a direct relationship between the two variables could not be established. Other factors such as technological change in rural work, educational offerings at universities, lower utility deals on health and education in some of the localities were also important in the process of depopulation within the province of Buenos Aires. 
Connection between APCP localities (-) get wer railwoy lines ACPC WPS (-) $1960-2001$

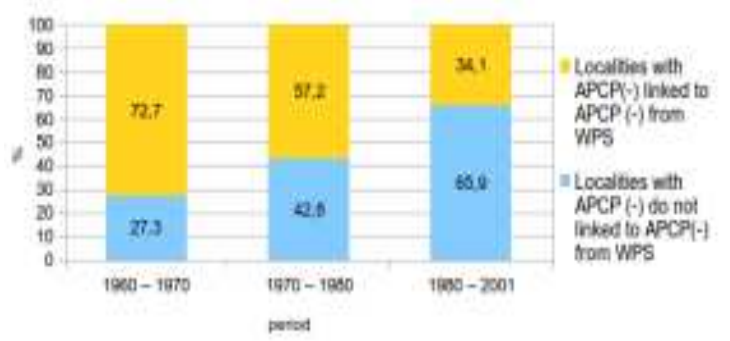

Figure 2. Connection between ACPC localities (-) set over railway lines ACPC WPS (-) $1960-2001$

The concept of the «space derivative» [7] remains important for understanding the relationship between territory (in the geographic sense) and the process of building the province of Buenos Aires. This means that the commands and interests that led to the installation of objects, founding of localities, and of relationships, brought about the extension of the railway network and the commercial actions that it facilitated. In this sense, the design of the rail network node in Buenos Aires and the ports of Bahia Blanca and Rosario did not foster an exchange in the interior of the province, but rather to these ports. In turn, the relevant aspect of the concept of «space derivative» implies that the construction of the space comes from external agents, external commands, and foreign interests. For localities inside the province of Buenos Aires, these interests were combined in the British and French companies who built railroads and telegraph lines to facilitate the needs of landowners to export their raw materials, transporting initially via local rail as [6] says, as service centers.

In this sense, the change in the use of technical objects as constituents of geographical space is relevant. The maps analyzed demonstrate the process of depopulation and the decline in rail passenger services. But it is necessary to enhance this type of analysis with more data from all variables. Some of this data may be periodization: paved roads, stocks of fuel stations, the number of inhabitants per automobile by location, among others. This may be a suggestion for future work. This study has required a lot of effort in obtaining historical sources, the burden of data transfer from paper books to digitization, and many elements remain for upload to further analysis.

Finally, it is considered necessary to build updated databases, an important necessary activity for both statistics, government and science in Argentina. The possibility of having such data would allow us to advance proposals and diagnosis with accuracy, which could be coupled with notions, concepts and analyses in conjunction with other methodologies.

\section{Maps Series}

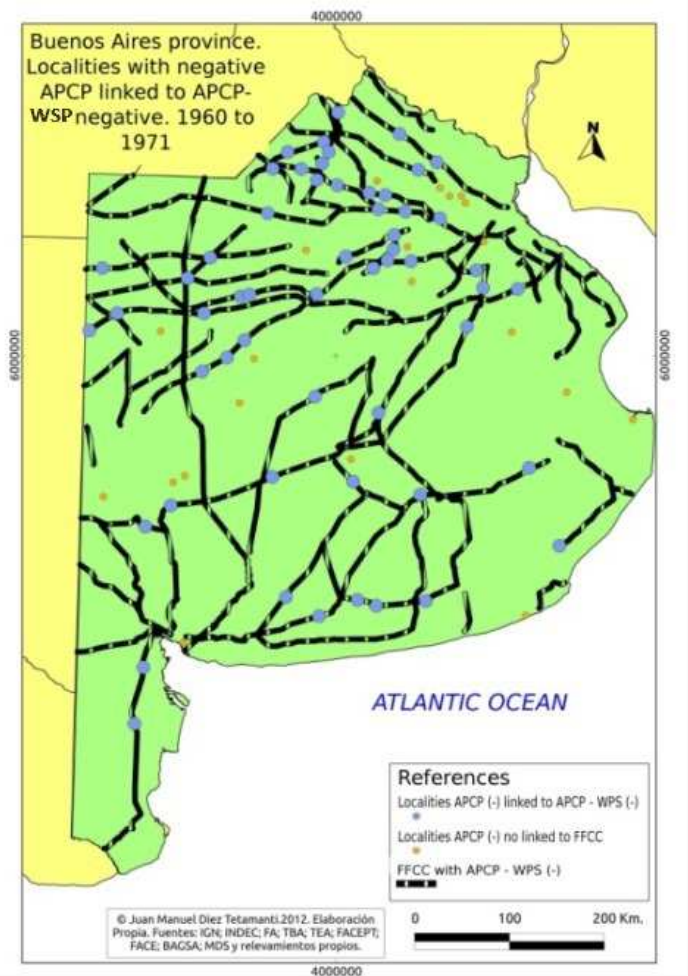

Map 2. Buenos Aires province. Localities with negative APCP-WSP negative. 1960 to 1971 .

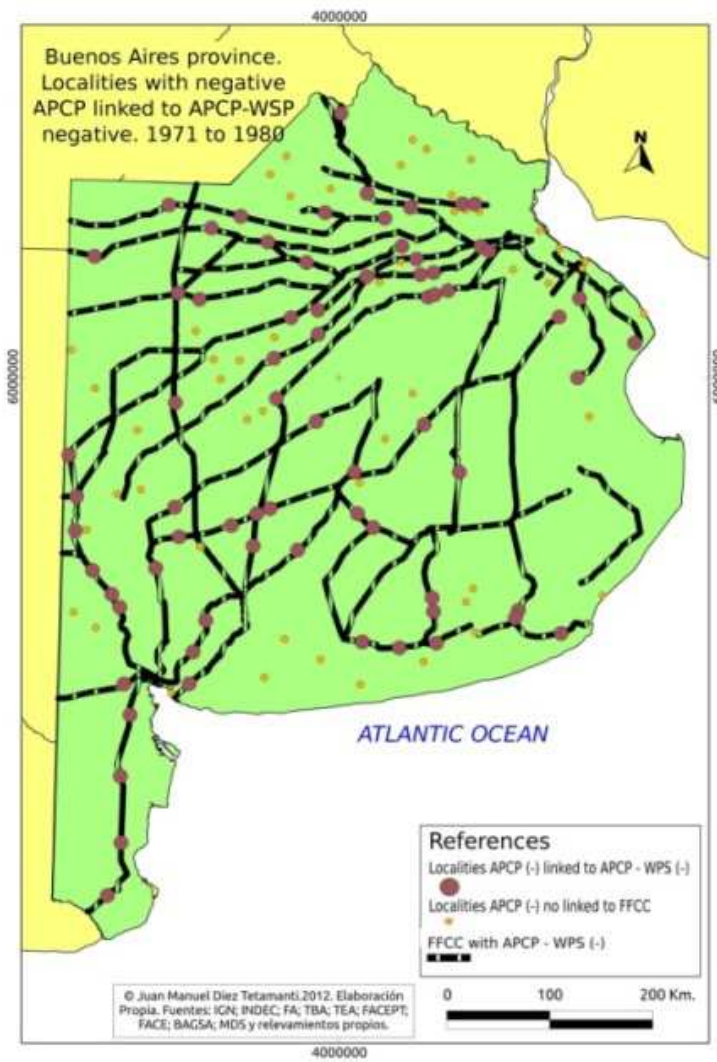

Map 3. Buenos Aires province.Localities with negative APCP linked to APCP-WSP negative. 1971 to 1980. 


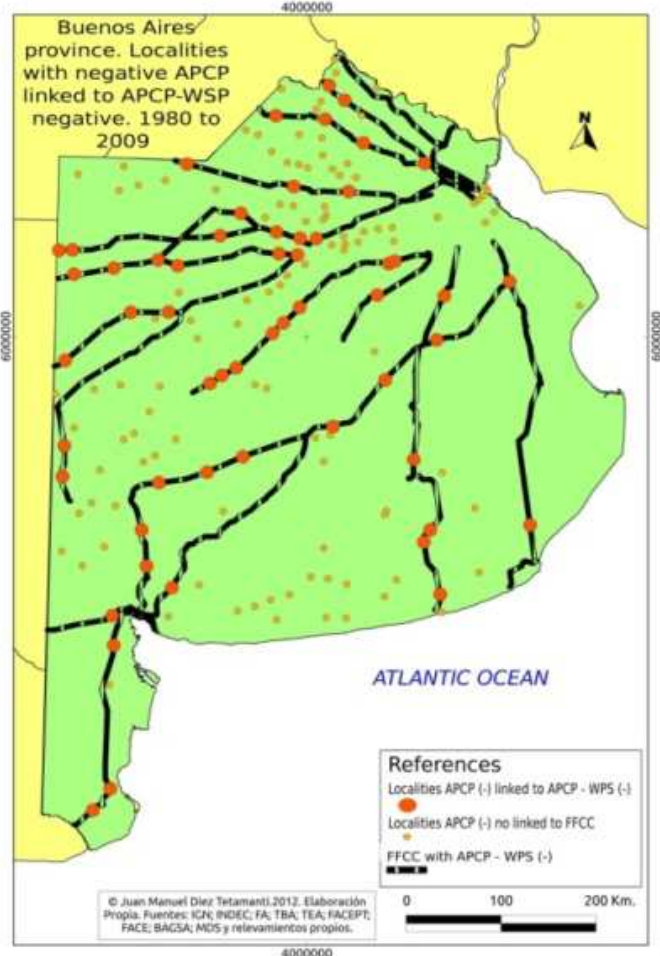

Map 4. Map 3. Buenos Aires province.Localities with negative APCP linked to APCP-WSP negative. 1980 to 2009.

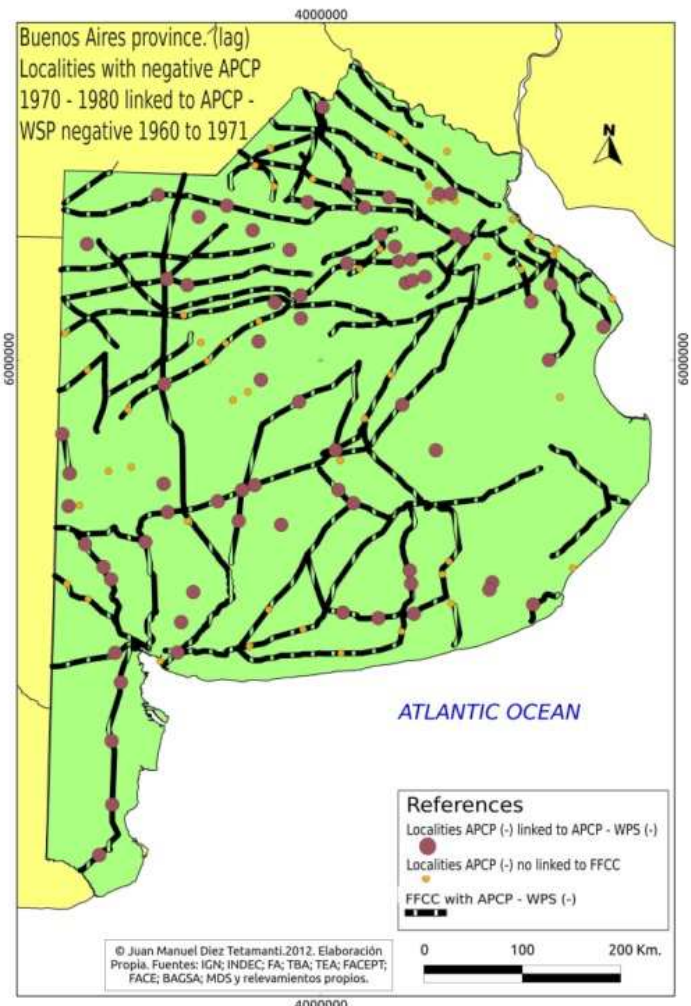

Map 5. Map 3.Buenos Aires province (lag).Localities with negative APCP 1970-1980 linked to APCP-WSP negative. 1960 to 1971.

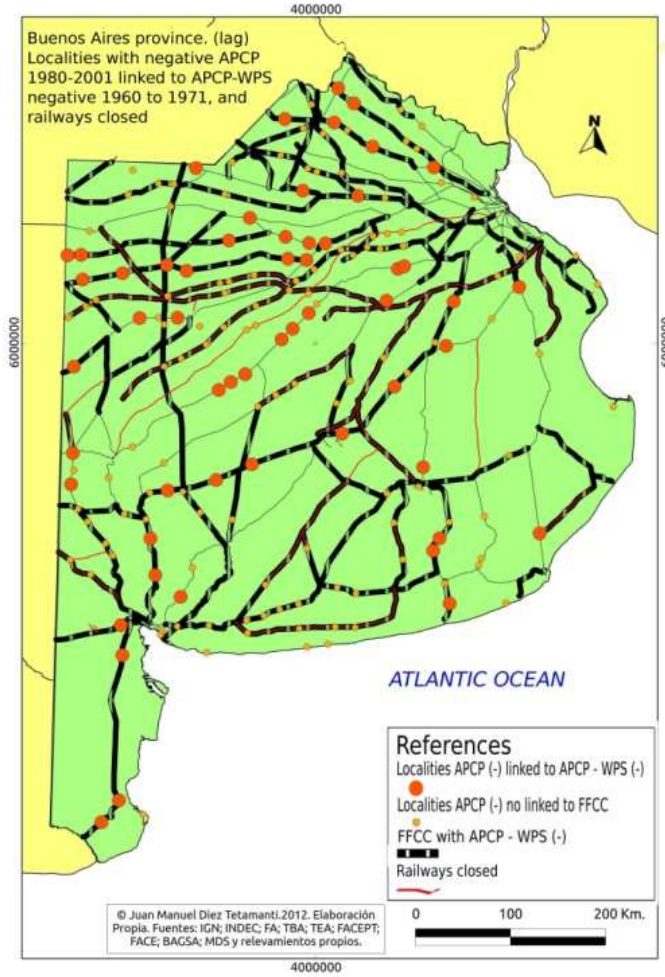

Map 6. Buenos Aires province (lag). Localities with negative APCP 1980-2001 linked to APCP-WSP negative. 1960 to 1971, and railways closed.

\section{Acknowledgements}

Thanks to CONICET for the financial support for this research, made through the Postdoctoral Fellowship from 2012 to 2014. At GIS Laboratory, Department of Geography, National University of Patagonia San Juan Bosco, for the contribution to this research of support shapes. Thanks to Asociacióndel Personal de Dirección de FerrocarrilesArgentinos (APDFA), for the contribution of information data which allowed evaluation of weekly passenger services. Thanks to specialist Cristina Massera, for suggestions on creating maps. This work has been supported by the "National Research Agency (ANR France) under SYSTERRA programme contained in the reference ANR-09-STRA04".

\section{Acronyms and Abbreviations}

GIS: Geographic Information System.

WGS: World Geodetic System.

INDEC: Instituto Nacional de Estadística y Censos (NationalInstitute of Statistics and Census).

TEA: TrenesEspecialesArgentinos (SpecialsArgentineTrains).

UEPFP: UnidadEjecutoradelProgramaFerroviario Provincial - (ExecutiveUnit of Provincial RailwayProgram).

GR: General Roca (railway line).

DFS: Domingo Faustino Sarmiento (railway line). 
GM: General Mitre(railway line).

GB: General Belgrano(railway line).

GU: General Urquiza(railway line).

GSM: General San Martín (railway line).

TBSA: Trenes de Buenos Aires - (Buenos Aires TrainsSA).

UGOFE: Unidad de Gestión Operativa Ferroviaria de Emergencia. (Railway Management and Operation Unit) APCP: Annual Percentage Changes of the Population. WPS: Weekly Services for Passenger.

FFCC: railway abbreviation from the Spanish.

\section{References}

[1] INDEC Instituto Nacional de Estadística y Censos 1947 a 1991. «Censo 1991». Provincia de Buenos Aires. Localidades. «Censo General de la Nación». Tomo I. Buenos Aires. Buenos Aires.

[2] Vapñarsky, César y otros 1998 «El concepto de localidad: definición, estudios de caso y fundamentos teóricos metodológicos», Serie D No 4, INDEC. Buenos Aires.

[3] Sili, M. 2000 «Los espacios de la crisis rural. Geografía de una pampa olvidada». Ed. UNS. Bahía Blanca.

[4] Ratier, Hugo y otros. 2004 «Poblados Bonaerenses, vida y milagros». Ed. La Colmena. Buenos Aires.

[5] Benítez, Marcela. 2000. «La Argentina que desaparece, desintegración de comunidades rurales y poblados en vías de desaparición». Univ. De Belgrano. $\mathrm{N}^{\circ} 12$. Buenos Aires

[6] Gaignard, R. 1979 «La pampa argentine. L'occupation du sol et la mise en valeur». Thèse de doctoratd'État, UniversitéBordeaux.

[7] Santos; M.1996 «De la totalidad al lugar». Ed. Oikos-tau. Barcelona.

[8] FA Ferrocarriles Argentinos. Itinerarios de Trenes. Temporadas 1961/71/80 y 1989. Series: $1961 / 71 / 80$ y 1989. Ed. Talleres Gráficos del Ferrocarril General Belgrano. Buenos Aires.

[9] TEA Trenes Especiales Argentinos 2009. Diagrama de trenes 2009. Buenos Aires.
[10] UGOFE Unidad de Gestión Operativa Ferroviaria de Emergencia 2009. Diagrama de trenes línea Roca 2009. Buenos Aires. Available in: http://www.ugofe.com.ar/general_roca/horarios/saladilloalve ar-ida.jpg

[11] Ferrobaires - UEPFP Unidad Ejecutora del Programa Ferroviario Provincial 2009. Diagrama de trenes de pasajeros. La Plata.

[12] Santos, Milton. 1986 «Espacio y Método». Revista Geocrítica. Año XII. Número: 65 Universidad de Barcelona.

[13] Calvo Palacios, J. L. y Pueyo Campos, A. (2008, Dir.):Atlas Nacional de España: Demografía. Madrid. Centro Nacional de Información Geográfica, 388 páginas

[14] Veschi, E. 2009 «Relato sobre el saqueo del sistema ferroviario nacional (1989-2005) y otros «daños colaterales»»»». Grupo Editor del Encuentro. Buenos Aires.

[15] Diez-Tetamanti, J. M. 2012. «Acciones locales y políticas públicas en pequeñas localidades de la provincia de Buenos Aires». Thesis Doctoral. Available in: http://books.google.com.ar/books?id=BWYTVTpQEoIC\&l $\mathrm{pg}=\mathrm{PA} 1 \& \mathrm{pg}=\mathrm{PA} 1 \mathrm{H}=$ onepage $\& \mathrm{q} \& \mathrm{f}=$ false

[16] ADEFA 2012. Asociación de fábricas de automotores. Estadísticas. Available in: http://www.adefa.com.ar

[17] Gartner, Andres 2011. «Estudio sobre tasa de motorización. Relaciones y determinantes». Available in: www.utn.edu.ar/download.aspx?idFile=17420Universidad Tecnológica Nacional. Buenos Aires. Argentina.

[18] Puliafito, E. 2010. «Transporte y calidad del aire informe \#4 opciones de mitigación de las emisiones de carbono para el sector transporte en argentina». Available en: www.frm.utn.edu.ar/ceds/Archivos/INF_N4_TRANSP_CEDS_UT N.pdf Buenos Aires. Argentina.

[19] Diez-Tetamanti, J.M. 2011. «Problemática demográfica en pequeñas localidades. Presentación de resultados cartográficos a partir de análisis demográficos y de cobertura de infraestructura y servicios públicos en la provincia de Buenos Aires entre 1947 y 2010. Modelos replicables para la unificación de datos con software libre». In. «Encuentro Binacional de Jóvenes Investigadores del Bicentenario Argentina Chile» Tomo Sur. Secretaría de PolíticasUniversitarias. Buenos Aires. 